\title{
$\therefore$ \\ Ethnopharmacological Relevance of Medicinal Plants from Karimnagar District, Telangana
}

\section{IJCRR}

Section: Healthcare

ISI Impact Factor

(2019-20): 1.628

IC Value (2019): 90.81

$\operatorname{SJIF}(2020)=7.893$

(c) (i) (8)

Copyright@IJCRR

\section{SM Shaheedha ${ }^{1}$, Sandeep Reddy Cheruku${ }^{2 *}$}

\author{
'Department of Pharmacognosy, Crescent School of Pharmacy, B.S Abdur Rahman Crescent, Institute of Science and Technology, Seethakathi \\ Estate, GST Road, Vandalur, Chennai-6ooo48, India; 'Department of Pharmacology, Marri Laxman Reddy Institute of Pharmacy, Dundigal, \\ Gandimaisamma (M), Hyderabad-500043, India.
}

\section{ABSTRACT}

Introduction: Natural medication (HM) is the support of correlative and elective medication, which lately is progressively acquiring boundless ubiquity everywhere in the world and slowly gushing toward coordination into the standard medical care frameworks.

Aim: This investigation was performed in Karimnagar district, Telangana state to report the ethnopharmacological information of two traditional herbs namely Mucuna pruriens Linn. Family: Fabaceae and Triumfetta pilosa Roth. Family: Malvaceae.

Methodology: Opinions from several traditional herb experts in the Karimnagar fields have been taken about the medicinal properties of these two herbs. Mucuna pruriens and Triumfetta pilosa have been reported to be used in several ailments.

Results: Mucuna pruriensis viewed as a nerve tonic, utilized in powdered form in leucorrhoea, spermatorrhoea, and so forth and as a sexual enhancer. pods are coved with solid hairs, which produce exceptional irritation of the skin. They are utilized as anthelmintic. Hairs mixed with honey have been used as a vermifuge. Triumfetta pilosa is an enduring spice or bush growing up to 3 meters tall. The plant is regularly frail stemmed and straying or climbing. The plant has a scope of neighbourhood utilizes, being reaped from the wild particularly for its fibre and restorative applications. An infusion of the Triumfetta pilosa leaf is drunk to treat colic and diarrhoea, though in East Africa a concentrate of the leaf is recorded to be drunk as a laxative. Leaf maceration is utilized as an eye shower for the treatment of eye problems. The squashed leaf and twig are applied as glue on sores. The bark and new leaves are astringent. They are utilized in the treatment of diarrhoea. The leaves and blossoms are utilized for the treatment of leprosy.

Conclusion: This Knowledge of the medicinal properties of Mucuna pruriens and Triumfetta pilosa could be helpful in novel drug discovery and to approve the ethnomedicinal information.

Keywords: Mucuna pruriens, Triumfetta pilosa, Karimnagar district, Ethnopharmacological, Medicinal properties, Drug discovery

\section{INTRODUCTION}

Mucuna pruriens (L) DC. (Syn. Dolichos pruriens L, Stizolobium pruriens Med.) (Fabaceae) is famously known as 'Khuhili' or 'Kawacha'. This has for quite some time been known and esteemed in Indian medication being referenced in Sushruta and Bhavaprakash. Seed is viewed as a nervine tonic, utilized in powdered structure in leucorrhoea, spermatorrhoea, and so forth and as an aphrodisiac. Pods are coved with firm hairs, ${ }^{1}$ which produce exceptional disturbance of skin. They are utilized as anthelmintic. Hairs blended in with nectar have been utilized as a vermifuge. A balm arranged with hairs goes about as a nearby energizer and gentle vesicant. The root is viewed as tonic and valuable in illnesses of the sensory sys- tem, for example, facial loss of motion and hemiplegia. Solid root implantation, with nectar, is given in cholera. It is considered as balya and advised in nephropathy, general weakness and nervous weakness. In Ayurveda, it has been described with different synonyms which describe its features.

\section{Types of Mucuna pruriens}

There are two kinds of Mucuna pruriens seeds are depicted. They are wild and developed. The wild assortment has preferred utility in clinical practice overdeveloped. As per seed tone, two sorts are clarified by certain creators as Swetha bija (white seed) \& krisna bija (dark seed). The dark seeds are considered as best than white. ${ }^{3}$

\section{Corresponding Author:}

Sandeep Reddy Cheruku, Associate Professor, Department of Pharmacology, Marri Laxman Reddy Institute of Pharmacy, Dundigal, Gandimaisamma (M), Hyderabad-500043, Medchal Dist. T.S, India; E-mail: sandeep97@gmail.com

ISSN: 2231-2196 (Print)

Received: 22.01 .2021
ISSN: 0975-5241 (Online)

Revised: 03.03 .2021
Accepted: 09.05.2021 


\section{Cultivation}

Kapikacchu Bija is occasionally cultivated. It is cultivated in the gardens and fields. Both the cultivated varieties have fewer trichomes and also had mild actions compared to the wild variety. Generally, cultivated variety is used as vegetables. $^{4}$

\section{Distribution and Habitat}

The plant is a herbaceous twining yearly, discovered all over India, regularly found in the tropics. Found wild all through India from the Himalayas to Cape Comorin in the plain locale and up to $3000 \mathrm{ft}$. rise in the slopes. It is additionally developed in equatorial jungle areas. It is regular in Bengal, Assam, Khasi slopes and Deccan as well as in the east and west coast area.

\section{Propensity and General Features}

Mucuna pruriens is a yearly climbing bush with semi-woody yearly or all the more frequently an enduring twinner delivering from its perenniality root framework, yearly shoots with slim terate branches that when youthful are typically dressed with short adpressed deflexed whitish hairs yet become glabrescent or just somewhat shaggy when full grown. It is nearly covered with fluffy hairs. ${ }^{5}$

Leaves: Fairly enormous, pinnately trifoliate, applaud, invert praise, rhombus moulded, substitute, specify, stipulesdeciduous, around 1/fifth inch long, stipels-minute, subulate. Rachises-three to five inches in length. Both sides of the leaves have hairs. Pamphlets three to four inches in length, by a few inches wide, on short, thick, sparingly deflexed shaggy stalks, praise rhomboid intense or subacute, mucronate, membranous, glabrous or glabrescent above and thickly covered with fine brilliant or gleaming dim adpressed hairs underneath. ${ }^{6}$

Blossoms: The bloom heads appear as pivotally showed panicles. They are short followed, huge, dull or offensive purple, turning dim when dry, $15-30 \mathrm{cms}$ long, with bracts and bracteoles, pedicles-short, typically more limited than the calyx. ${ }^{7}$ Calyx-gamosepalous, around seventy-five per cent of an inch since quite a while ago, covered outside with whitish satiny hairs intermixed with a couple of aggravation bristles. The ringer is long and plush. The sepals are longer and the crown is purplish or white.

Corolla: Itis papilionaceous, much applied, purplish, one and a quarter to one and a half-inch long. ${ }^{8}$

Stamens: Di-Adolphus, then again more; anthers-dimorphous, on the other hand, oval, and ovate and round and sagittate. Pistil-monocarpellary. Ovary-sessile, villous, many ovulated.

Fruit: A bloated violently dehiscing case, a few or four inches in length, and about half an inch wide, marginally falcate bent of the two finishes. At the organic product ageing stage $4-13 \mathrm{cms}$ long, $1-2 \mathrm{cms}$ wide, unwinged, leguminous natural product created and moulded like the letter obtuse of one or the flip side and marginally longitudinally furrowed. The organic product containing four to at least six seeds with septa or allotments between the seeds. The natural product valves are not fallen, however, cleaned inside. ${ }^{9,10}$

Seeds: Seeds are ovoid or dynamically elliptical, somewhat along the side packed with a cleaned dim, earthy or dark or sometimes mottled testa. The seeds are sparkling dark or earthy coloured float seeds. Figure No.1 indicates the different parts of Macuna Pruriens plant which have tremendous medicinal benefits.
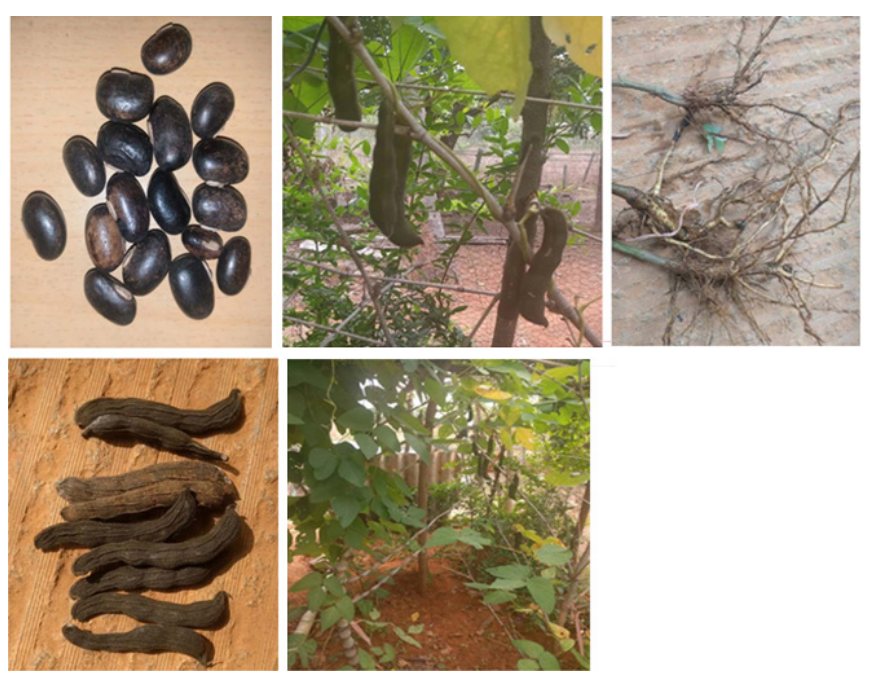

Figure 1: Mucuna pruriens plant, fruits, roots \& seeds.

\section{Triumfetta pilosaRoth}

\section{Description}

Little bush of Triumfetta pilosa $1.3 \mathrm{~m}$ tall; stems regularly quadrangular, sparingly stellate-pubescent or thickly tomentose, hair-bases frequently tubercled. Leaf-lamina 5-12 $\times$ 3-7 cm., applaud to elliptical lanceolate, intensely taper or intense at the summit, edge coarsely serrate, adjusted to cordate at the base, puberulous or pubescent or thickly tomentose particularly beneath; petiole up to c. $5 \mathrm{~cm}$. long; stipules up to $0.8 \mathrm{~cm}$. long, subulate. Inflorescences verdant, of little cymes swarmed at the hubs; peduncles of cymes and pedicels short, up to $5 \mathrm{~mm}$. long, yet frequently less; bracts $2-4$ $\mathrm{mm}$. long, straight or lanceolate-direct, setulose-pubescent. Sepals 7-10 mm. long, straight, pubescent or tomentose; subapical horn extremely short, $1 \mathrm{~mm}$. long. Petals yellow, somewhat more limited than the sepals, direct to oblanceolate-straight, ciliate at the base. Androgynophore up to 0.75 $\mathrm{mm}$. tall, organs orbicular; annulus thickly hirsute above. Stamens 8-10. Ovary globose, echinulate, 3-4-locular. Natural product $1.5-2.7 \mathrm{~cm}$. in diameter, counting the aculei; 
aculei $0.5-1 \mathrm{~cm}$. long, glabrous or pilose, uncinate at the pinnacle. ${ }^{11,12}$

Synonyms: T.cana Blume

\section{Vernacular Names:}

Telugu: Teega benda, Pedda antrintha.

\section{Conventional Uses:}

- Whole plant is utilized in treatment of diabetes.

- Barks and leaves are utilized in treatment of loose bowels.

- Leaves and blossoms are utilized for the treatment of Leprosy. ${ }^{13}$

- Fatty acids present in seed oil utilized for business.

\section{Substance constituents:}

$\begin{array}{ll}\text { Palmitic acid } & 16.7 \% \\ \text { Stearic acid } & 10.8 \% \\ \text { Oleic acid } & 20.1 \% \\ \text { Linoleic acid } & 43.4 \% \\ \text { Malvalic acid } & 2.4 \% \\ \text { Sterulic acid } & 6.6 \%\end{array}$

\section{Scientific categorization:}

$\begin{array}{lll}\text { Species } & : & \text { Triumfetta pilosa } \\ \text { Kingdom } & : & \text { Plantae } \\ \text { Phylum } & : & \text { Spermatophyta } \\ \text { Sub-phylum } & : & \text { Angiospermae } \\ \text { Class } & : & \text { Magnoliopsida } \\ \text { Order } & : & \text { Malvales } \\ \text { Family } & : & \text { Tiliaceae }\end{array}$
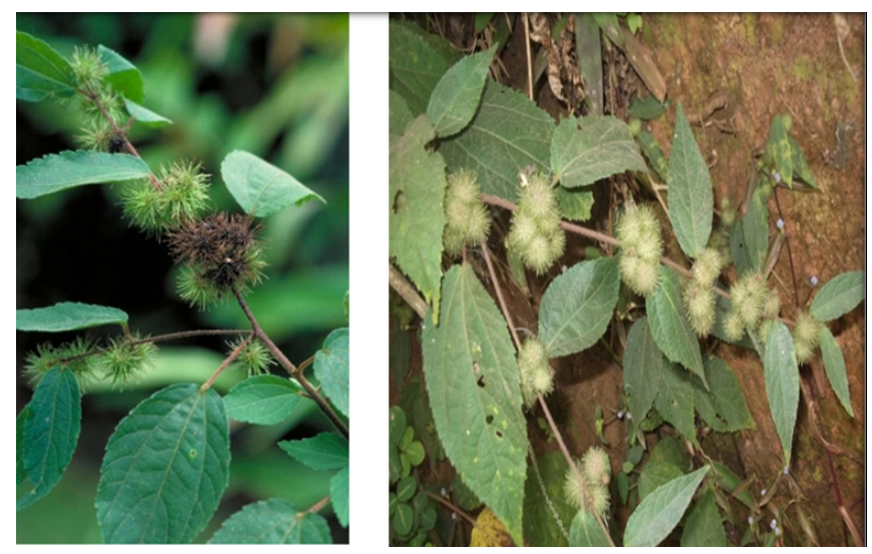

Figure 2: Ripening fruits and fruiting stem of Triumfetta pilosa plant.

Figure 2 indicates Triumfetta pilosa plant fruits (ripened) and fruiting stem which has been utilized for the treatment of various health ailments.

\section{CONCLUSION}

There has been tremendous increase in the consumption and demand for medicinal plants in last decade. Scientific research on medicinal plants such as Mucuna pruriens and Triumfetta pilosa in telangana is opening new horizons in the potential of medicines and other natural products. Although, only $20 \%$ of the plant flora has been studied and around $60 \%$ of synthetic medicines are originated from plants. The essential oil, flavours, fragrances of aromatic plants at industrial level contribute to economy of developing countries by export earnings and import substitution. Organoprotective ingredients present in Mucuna pruriens and Triumfetta pilosa play a significant role in general and management of human clinical conditions. But till date the organoprotective properties of Mucuna pruriens and Triumfetta pilosa have not been explored scientifically. Karimnagar district and its vicinity have been considered as a hub for several medicinal plants and telangana government is encouraging the scientific exploration of new species of plants. Hence it is necessary to explore the traditionally reported Pharmacological activities of plants such as Mucuna pruriens and Triumfetta pilosa by various in vitro and in vivo studies.

\section{ACKNOWLEDGEMENTS}

The authors are thankful to several traditional herb experts in the Karimnagar for describing the medicinal properties of the selected plants. The authors are also thankful to the management of Marri Laxman Reddy Institute of Pharmacy, Hyderabad for encouraging to carry out the review on medicinal plants.

\section{Conflict of Interests}

This is to inform that the authors declare that they have no conflict of interest with respect to this article.

\section{Financial Support}

None

\section{Authors Contribution}

Sandeep Reddy Cheruku has designed and drafted the manuscript and SMShaheedha has done the critical and final revision of the manuscript.

\section{REFERENCES}

1. Nadkarni KM. Indian materia medica: With ayurvedic, unanitibbi, siddha, allopathic, homeopathic, naturopathic and home remedies, appendices and indexes-Vol. 2. Ramdas Bhatkal, Popular Prakashan Private Ltd; 1976.

2. Balandrin MF, Kinghorn AD, Farnsworth NR. Plant-derived natural products in drug discovery and development: an overview. 
3. Anonymous, The Ayurvedic Pharmacopoeia of India, 1st edition., New Delhi; Ministry of Health \& Family Welfare. (ISM \& H): 2001; 1(3):23-24.

4. Arvigo R, Balick MJ, Evans L. Rainforest remedies: One hundred healing herbs of Belize. Lotus Press; 1993.

5. Lorenzetti E, MacIsaac S, Arnason JT, Awang DVC, Buckles D. The phytochemistry, toxicology and food potential of velvet bean (MucunaAdans spp., Fabaceae) Cover crops of West Africa: contributing to sustainable agriculture. Ind Drug Rres Cen, Ottawa, Canada \& IITA, Ibadan, Nigeria.1998; 57.

6. Damodaran M, Ramaswamy R. Isolation of 1-3: 4-dihydroxyphenylalanine from the seeds of Mucuna pruriens. Biochem. 1937 Dec;31(12):2149.

7. Ghosh G. A note on pharmacognostic and chemical identification of Mucuna utilise seed, a substitute of Mucuna pruriens. Indian drugs. 1982;20:24.

8. Ghosh G. Pharmacognostic study of Mecuna pruriens Baker non DC seed. Nagarjun. 1983;27:9.
9. Jackson MI. Soil Chemical Analysis, Prince Hall of India Ltd. New Delhi, India. 1973.

10. Johansen, D.A. Plant Microtechnique, Tata McGraw Hill Publishing Company Ltd., New Delhi, India, 1940.

11. Madhava Chetty K, Sivaji K, Tulasi Rao K. Flowering plants of Chittoor district, Andhra pradesh, India. Published by Students Offset Printers, Tirupati. 2008;61.

12. Pergaud SL, Hannewald P, Yemloul M, Kirsch G, Tchaleu Ngadjui B. Triumfettamide and Triumfettoside Ic, two ceramides and other secondary metabolites from the stems of wild Triumfetta cordifolia A. Rich.(Tiliaceae). Helvetica Chimica Acta. 2008 Jul;91(7):1326-35.

13. Konijeti SR, Kumar KS, Movva SL, Muralikrishna KS. Evaluation of Anxiogenic Effect of Pseudoephedrine in Albino mice. Int J Cur Res Rev. 2020 Sep 22;12(18):42. 